\title{
Usefulness of exercise tissue doppler echocardiography for prognostic stratification of congestive heart failure patients with left ventricular systolic dysfunction
}

\author{
Ondrej Ludkaa , Jan Trna ${ }^{b}$, Lujza Galkovaa ${ }^{a}$ Viktor Musilia, Jindrich Spinar ${ }^{a}$
}

\begin{abstract}
Aim. Determination of the importance of exercise tissue Doppler echocardiography in prognostic stratification of congestive heart failure patients with systolic dysfunction.

Methods. 106 patients with congestive heart failure and LVEF $\leq 45 \%$ on optimal pharmacotherapy were included in the study. Results of resting and post-exercise echocardiography, cardiopulmonary exercise test and serum BNP levels were available for all patients. Two patient groups were constituted, based on the prognostic classification. Group I contained 21 patients with poor prognosis (defined by predicted value of pVO2 $<76 \%$ together with both VE/VCO2 slope $>32.7$ and BNP > $210 \mathrm{pg} / \mathrm{mL}$ ) and group II with 85 patients who did not meet the criteria.

Results. The patient groups significantly differed in indexed volume of left atrium, mitral regurgitation severity, rest and post-exercise systolic velocity of mitral annulus and in rest and post-exercise E/Em. Multivariate analysis identified E/ Em as the only independent predictor of prognosis. E/Em at rest (post-exercise) $\geq 16.6$ ( $\geq 18.7$ ) defined poor prognosis with sensitivity of $71 \%$ (86\%) and specificity of $71 \%(71 \%)$.

Conclusion. Our study suggests usefulness of exercise tissue Doppler echocardiography for prognostic stratification of patients with congestive heart failure with possible superiority to resting parameters.
\end{abstract}

Key word: exercise echocardiography, heart failure, prognosis

Received: August 23, 2011; Accepted: January 4, 2012; Available online: February 17, 2012 http://dx.doi.org/10.5507/bp.2012.014

anternal Cardiology Department, University Hospital Brno and Faculty of Medicine, Masaryk University Brno, Czech Republic 'Internal Gastroenterology Department, University Hospital Brno and Faculty of Medicine, Masaryk University Brno Corresponding author: Ondrej Ludka, e-mail: oludka@fnbrno.cz

\section{INTRODUCTION}

Echocardiography represents an essential method in diagnostics, management and prognostic stratification of patients with chronic heart failure $(\mathrm{CHF})\left(\right.$ ref. $\left.^{1}\right)$. The interest in traditional heart function indicators such as left ventricular ejection fraction (LVEF), which has been shown to be of prognostic value in large cohorts of patients with $\mathrm{CHF}$ followed in extensive pharmacological studies $^{2,3}$, has shifted with technical progress and new echocardiographic methods to newer parameters assessing left ventricular diastolic function ${ }^{4}$, left ventricular filling pressure ${ }^{5}$, or systolic and diastolic right ventricular function ${ }^{6}$.

Recent attention has been brought to the evaluation of resting and postexercise heart function parameters in a more comprehensive way than simply the comparison of LVEF. Some studies indicate better potential of exercise echocardiographic parameters as for function capacity ${ }^{7,8}$. Potential significance of exercise echocardiography likely results from the fact, that a significant portion of $\mathrm{CHF}$ patients are symptomatic mainly during exercise and function capacity is a standard examination algorithm in prognostic stratification when considering heart transplantation ${ }^{1}$. Treatment management can be greatly influenced by knowledge about left ventricular exercise reaction. The target of our work has been the evaluation of exercise tissue Doppler echocardiography in prognostic stratification of CHF patients and the measurement of its specificity and sensitivity compared to parameters obtained during only resting studies.

\section{MATERIAL AND METHODS}

We studied 106 heart failure patients with LVEF $\leq$ $45 \%$ with dilatation cardiomyopathy or ischemic heart disease, who were recommended to pass the ergometry test for clinical indications by their heart failure specialist. The clinical research ethics committee approved this study, and all subjects signed informed consent.

Enrollment criteria included age over 18, history of heart failure $\geq 6$ months, clinically stable condition $\geq 3$ preceding months, acute coronary syndrome or elective myocardial revascularization $\geq 6$ months, good echocardiographic examinability, ability to pass ergometry and optimal heart failure pharmacotherapy according to latest guidelines ${ }^{1}$ providing there was no contraindication or intolerance, and the willingness of the patients to participate in this study.

Exclusion criteria have been defined as severe disorder of ventilation (corticoid therapy necessity or presence 
of respiratory insuficiency at rest), ischemic response to exercise that passes the definition of a new kinetic disorder, valvular dysfunction of at least mild severity (in case of mitral regurgitation ERO $>0.2 \mathrm{~cm}^{2}$ regardless to etiology of the pathology), hypertrophic or restrictive cardiomyopathy, anemia (hemoglobin $<120 \mathrm{~g} / \mathrm{L}$ for women, and $<130 \mathrm{~g} / \mathrm{L}$ for men), assessed glomerular filtration $<30 \mathrm{~mL} / \mathrm{min}$ (according to Cockroft-Gault formula) and presence of pacemaker or implantable cardioverterdeffibrilator.

Enrollment criteria have been met by 106 patients of average age of $64.1 \pm 13.4$ years, 20 (19\%) were female.

Protocol consisted of clinical examination, blood sampling at standard conditions from the cubital vein for haemathologic and biochemic examination with determining the BNP level. Determination of the BNP level was carried out at the University hospital Brno central laboratory within $20 \mathrm{~min}$ of the blood sample collection. Diagnostic sets Axsym from Abbott were used for assessment. Afterwards, the patients underwent resting echocardiographic examination with bicycle spiroergometry. The exercise pulse Doppler and tissue Doppler echocardiography were recorded immediately after the exercise test.

Exercise spiroergometry test was carried out at Ergoline 900 ergometer using Jaeger Oxycon Delta, Erich Jaeger $\mathrm{GmbH}$ system for expired gases analysis. Its sensors were calibrated with a gas of known nitrogen, oxygen and carbon dioxide concentration before every test. The flow rate sensor was calibrated before every test, too. We used a ramp protocol with continuous increase of $10 \mathrm{~W} / \mathrm{min}$. Peak values were calculated as the average of a $30 \mathrm{~s}$ interval before the exercise end, and besides the absolute values (in $\mathrm{mL} / \mathrm{kg} / \mathrm{min}$ ) we also calculated the percentage ratio adjusted to the subject's age and gender. Exercise test was drawn up as maximal, symptom limited. For calculation of parameter VE/VCO, slope we used 10 $\mathrm{s}$ averages of minute ventilation (VE) and rate of elimination of carbon dioxide ( $\mathrm{VCO} 2$ ) in the linear part of the $\mathrm{VE}(\operatorname{ax~} \mathrm{Y}) \mathrm{VCO}_{2}(\mathrm{ax} \mathrm{X})$ curve that were processed as two corresponding (time synchronized) columns in Microsoft Excel and using the "slope" function the calculation of parameter value (Fig. 1) was executed.

Basic echocardiographic measurements were carried out according to latest guidelines of American Society of Echocardiograpy ${ }^{8}$. LVEF was calculated according to biplanar disc method, left atrial volume according to biplanar method length-width in 4-chamber and 2-chamber apical projection. The values were indexed to the body surface.

Mitral regurgitation was calculated by PISA method ${ }^{9}$ (group 1 with no or trace regurtitation, group 2 with regurgitation orifice area $\mathrm{ROA}<0.1 \mathrm{~cm}^{2}$ and group 3 with ROA $<0.2 \mathrm{~cm}^{2}$ ). Wave E of early mitral flow was measured at rest or after exercise by pulse Doppler using $5 \mathrm{~mm}$ sampling volume positioned at the level of free mitral valve point edges in diastole. Myocardial speeds were set during rest and after exercise with tissue Doppler imaging (TDI) using 2 to $5 \mathrm{~mm}$ sampling volume positioned at the lateral and septal mitral anulus and lateral tricuspid anulus, Nyquist limit was set to $15-20 \mathrm{~cm} / \mathrm{s}$. Systolic wave ( $\mathrm{Sm}$ during rest and Sm' after exercise) and early diastolic mitral anulus wave (Em during rest and Em' after exercise) were calculated as the measurement average of septal and lateral mitral anulus regarding the present focal kinetic dysfunctions by great number of patients ${ }^{10-12}$. Systolic tricuspid anulus wave (Stri) was measured only during rest. All the postexercise Doppler measurements were realized between the $2^{\text {nd }}$ and $5^{\text {th }}$ minute after the exercise test end $^{12-14}$. after the end of the standard projection record for left ventricle kinetics assessment. We calculated the average of 3 measurements of patients with sinus rhythm and of 5 measurements of patients with atrial fibrillation.

Comparison of the groups in cathegorial parameters was carried out with Fisher exact tests. Metric data was tested with Shapiro-Wilks normality tests. Parameters where the normal distribution was determined were processed with parametric Student t-tests. The majority of quantitative data wasn't characterized by normal distribution, comparing the groups in these parameters was carried out with nonparametric Mann-Whitney tests. Logistic regression in forward stepwise likelihood ratio organisation was used for multidimensional analysis to identify the independent predictors of poor prognosis. The independent variables, which demonstrated statistically significant difference in univariant testing between the compared groups, were characterised by the logistic regression. Colinearity between the independent predictors entering the multidimensional analysis was eliminated by VIF testing (variation inflation factors) with the critic value of 5 . Reliability of the models was compared using Nagelkerke $\mathrm{R}^{2}$ coefficient. Optimal cut-off value of the independent variable was searched using the ROC curves for prediction of prognostically poor result. All the tests were carried out on statistic significance level $P=0.05$. Statistically significant significance levels are highlighted in bold in the tables.

Group was divided into two parts (group I and II). Group I consisted of patients with prognostically poor finding defined as simultaneous presence of following values:

1. The actual oxygen consumption rate lower than the median (76 percent of the appropriate value)

2. VE/VCO2 slope higher than median (32.7)

3. BNP higher than median $(210 \mathrm{pg} / \mathrm{mL})$

The group consisted of patients with low oxygen consumption, high VE/VCO2 slope and high BNP level. Group II comprised of all the other patients not meeting the criteria for the group I.

\section{RESULTS}

Table 1a,b summarizes demographic characteristics, comorbidities, treatment and function class NYHA patients in both groups.

Table 2 depicts exercise parameters and renal functions in both groups.

Echocardiographic parameters in both groups during 
Table 1a,b. Demographic characteristics, comorbidities, treatment and function class NYHA in both groups.

Table 1a

\begin{tabular}{cccccc}
\hline \multicolumn{5}{c}{ Group $\mathrm{I}(\mathrm{N}=21)$} & \multicolumn{2}{c}{ Group II $(\mathrm{N}=85)$} \\
\hline Parameter & Median (Interval) & Mean $\pm \mathrm{SD}$ & Median (Interval) & Mean \pm SD & $P$ \\
\hline Age (year) & $70.0(45-83)$ & $67.4 \pm 10.3$ & $65.0(32-85)$ & $63.2 \pm 13.9$ & $0.291^{\mathrm{b}}$ \\
BMI $\left(\mathrm{kg} / \mathrm{m}^{2}\right)$ & $27.1(19.1-34.3)$ & $27.1 \pm 4.0$ & $27.8(18.3-41.8)$ & $28.2 \pm 4.8$ & $0.536^{\mathrm{b}}$ \\
\hline
\end{tabular}

${ }^{\mathrm{b}}$ Mann-Whitney test

Table 1b

\begin{tabular}{|c|c|c|c|c|}
\hline Parameter & Category & $\begin{array}{c}\text { Group I }(\mathrm{N}=21) \\
\text { No. }(\%)\end{array}$ & $\begin{array}{c}\text { Group II }(\mathrm{N}=85) \\
\text { No. }(\%)\end{array}$ & $P$ \\
\hline Sex & $\begin{array}{l}\text { Men } \\
\text { Women }\end{array}$ & $\begin{array}{l}16(76.2) \\
5(23.8)\end{array}$ & $\begin{array}{l}70(82.3) \\
15(17.7)\end{array}$ & $0.539^{\mathrm{a}}$ \\
\hline Etiology of CHF & $\begin{array}{l}\text { DCMP } \\
\text { CAD }\end{array}$ & $\begin{array}{l}6(28.6) \\
15(71.4)\end{array}$ & $\begin{array}{l}44(51.8) \\
41(48.2)\end{array}$ & $0.086^{\mathrm{a}}$ \\
\hline Diabetes mellitus & $\begin{array}{l}\text { Yes } \\
\text { No }\end{array}$ & $\begin{array}{l}9(42.9) \\
12(47.1)\end{array}$ & $\begin{array}{l}26(30.6) \\
59(69.4)\end{array}$ & $0.308^{\mathrm{a}}$ \\
\hline Hypertension & $\begin{array}{l}\text { Yes } \\
\text { No }\end{array}$ & $\begin{array}{r}16(76.2) \\
5(23.8)\end{array}$ & $\begin{array}{l}48(56.5) \\
37(43.5)\end{array}$ & $0.135^{\mathrm{a}}$ \\
\hline Atrial fibrilation & $\begin{array}{l}\text { Yes } \\
\text { No }\end{array}$ & $\begin{array}{l}6(28.6) \\
15(71.4)\end{array}$ & $\begin{array}{l}12(14.1) \\
73(85.9)\end{array}$ & $0.190^{\mathrm{a}}$ \\
\hline Furosemide & $\begin{array}{l}\text { Yes } \\
\text { No }\end{array}$ & $\begin{array}{l}20(95.2) \\
1(4.8)\end{array}$ & $\begin{array}{l}76(89.4) \\
9(10.6)\end{array}$ & $0.683^{\mathrm{a}}$ \\
\hline Spironolactone & $\begin{array}{l}\text { Yes } \\
\text { No }\end{array}$ & $\begin{array}{l}14(66.7) \\
7(33.3)\end{array}$ & $\begin{array}{l}54(63.5) \\
31(36.5)\end{array}$ & $1.0^{\mathrm{a}}$ \\
\hline ARB/ACEI & $\begin{array}{l}\text { Yes } \\
\text { No }\end{array}$ & $\begin{array}{c}20(95 ., 2) \\
1(4.8)\end{array}$ & $\begin{array}{c}84(98.8) \\
1(1.2)\end{array}$ & $0.358^{\mathrm{a}}$ \\
\hline Betablocker & $\begin{array}{l}\text { Yes } \\
\text { No }\end{array}$ & $\begin{array}{l}20(95.2) \\
1(4.8)\end{array}$ & $\begin{array}{c}84(98.8) \\
1(1.2)\end{array}$ & $0.358^{\mathrm{a}}$ \\
\hline Statin & $\begin{array}{l}\text { Yes } \\
\text { No }\end{array}$ & $\begin{array}{c}19(90.5) \\
2(9.5)\end{array}$ & $\begin{array}{l}51(60.0) \\
34(40.0)\end{array}$ & $0.009^{\mathrm{a}}$ \\
\hline NYHA & $\begin{array}{l}1 \\
2 \\
3\end{array}$ & $\begin{array}{l}7(33.3) \\
9(42.9) \\
5(23.8)\end{array}$ & $\begin{array}{c}22(25.9) \\
57(67.1) \\
6(7.0)\end{array}$ & $0.038^{\mathrm{a}}$ \\
\hline
\end{tabular}

${ }^{a}$ Fisher exact test

NYHA 1 (NYHA <II) NYHA 2 (NYHA II and II-III) NYHA 3 (NYHA III and III-IV) 
Table 2. Exercise parameters and renal functions in both groups.

\begin{tabular}{lccccc}
\hline \multicolumn{4}{c}{ Group I $(\mathrm{N}=21)$} & \multicolumn{2}{c}{ Group II $(\mathrm{N}=85)$} \\
\hline Parameter & Median (Interval) & Mean \pm SD & Median (Interval) & Mean \pm SD & $P$ \\
\hline pVO2 $[\mathrm{mL} / \mathrm{kg} / \mathrm{min}]$ & $11.4(7.3-19.1)$ & $12.5 \pm 3.1$ & $19.2(9.4-39.9)$ & $19.6 \pm 5.7$ & $\mathbf{< 0 . 0 0 0 1}^{\text {b }}$ \\
Work tolerance $[\mathrm{W} / \mathrm{kg}]$ & $1.00(0.60-1.60)$ & $0.99 \pm 0.28$ & $1.26(0.4-2.04)$ & $1.54 \pm 0.21$ & $\mathbf{0 . 0 0 5}^{\text {b }}$ \\
RER & $0.98(0.81-1.40)$ & $1.02 \pm 0.14$ & $1.01(0.80-1.38)$ & $1.01 \pm 0.13$ & $0.978^{\text {b }}$ \\
GFR [mL/min] & $60(30-105)$ & $58 \pm 19$ & $77(30-156)$ & $77 \pm 30$ & $\mathbf{0 . 0 0 5}^{\text {b }}$ \\
\hline
\end{tabular}

${ }^{\mathrm{b}}$ Mann-Whitney test

Table 3. Echocardiographic parameters in both groups during rest (without index) and after exercise (with index ').

\begin{tabular}{lccccc}
\hline Parameter & \multicolumn{2}{c}{ Group I $(\mathrm{N}=21)$} & \multicolumn{2}{c}{ Group II $(\mathrm{N}=85)$} \\
\hline MR & No. & $(\%)$ & No. & $(\%)$ & $P$ \\
$1 / 2 / 3$ & $9 / 9 / 3$ & $42.9 / 42.9 / 14.2$ & $67 / 13 / 5$ & $78.8 / 15.3 / 5.9$ & $\mathbf{0 . 0 0 4}^{\mathrm{a}}$ \\
& Median (Interval) & Mean \pm SD & Median (Interval) & Mean \pm SD & $P$ \\
EDVi $\left[\mathrm{mL} / \mathrm{m}^{2}\right]$ & $105.0(53.3-173.6)$ & $106.6 \pm 34.2$ & $93.5(55.6-195.5)$ & $103.2 \pm 32.1$ & $0.649^{\mathrm{b}}$ \\
ESVi $\left[\mathrm{mL} / \mathrm{m}^{2}\right]$ & $74.1(32.1-133.1)$ & $76.1 \pm 30.8$ & $61.6(31.6-153.5)$ & $69.3 \pm 27.6$ & $0.381^{\mathrm{b}}$ \\
EF $[\%]$ & $29.1(16.7-44.1)$ & $30.6 \pm 8.8$ & $34.8(14.7-44.9)$ & $34.2 \pm 6.8$ & $0.09^{\mathrm{c}}$ \\
LAvoli $\left[\mathrm{mL} / \mathrm{m}^{2}\right]$ & $54.6(28.1-81.9)$ & $55.9 \pm 13.8$ & $41.6(16.9-106.1)$ & $45.4 \pm 17.2$ & $\mathbf{0 . 0 0 2}^{\mathrm{b}}$ \\
Sm $[\mathrm{cm} / \mathrm{s}]$ & $4.1(2.5-9.4)$ & $4.46 \pm 1.61$ & $5.80(3.0-10.00)$ & $5.96 \pm 1.37$ & $\mathbf{0 . 0 0 0 0 4}^{\mathrm{c}}$ \\
S tri $[\mathrm{cm} / \mathrm{s}]$ & $9.2(5.2-14.4)$ & $9.78 \pm 2.55$ & $10.2(5.4-18.0)$ & $10.94 \pm 2.54$ & $0.065^{\mathrm{b}}$ \\
E/Em & $22.9(9.7-40.7)$ & $23.8 \pm 9.6$ & $12.9(5.4-49.3)$ & $14.3 \pm 6.7$ & $\mathbf{0 . 0 0 0 0 3}^{\text {b }}$ \\
Sm' $[\mathrm{cm} / \mathrm{s}]$ & $5.0(3.1-11.4)$ & $5.5 \pm 2.2$ & $7.8(3.9-14.4)$ & $7.6 \pm 1.9$ & $\mathbf{0 . 0 0 0 0 2}^{\mathrm{b}}$ \\
E'/E'm & $26.5(10.3-44.4)$ & $27.4 \pm 9.3$ & $15.6(6.0-44.4)$ & $16.7 \pm 7.0$ & $0.000002^{\mathrm{b}}$ \\
\hline
\end{tabular}

${ }^{a}$ Fisher exact test, ${ }^{\mathrm{b}}$ Mann-Whitney test, ${ }^{\mathrm{c}}$ Student t-test

Table 4. Prediction of prognostically poor state with resting TDI parameters.

\begin{tabular}{ccccccc}
\hline \multirow{2}{*}{ Model } & Parameter & Odds ratio & \multicolumn{2}{c}{$95 \% \mathrm{CI}$} & $\mathrm{R}^{2}$ \\
& & Lower limit & Upper limit & & \\
\hline \multirow{2}{*}{ TDI at rest } & $\begin{array}{c}\text { E/Em } \\
\text { rises by } 5 \text { unit }\end{array}$ & 1.961 & 1.397 & 2.755 & $<0.001$ & $0.275^{\mathrm{a}}$ \\
\hline
\end{tabular}

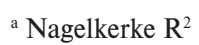

Table 5. Prediction of prognostically poor state using after exercise TDI parameters.

\begin{tabular}{ccccccc}
\hline \multirow{2}{*}{ Model } & Parameter & Odds ratio & \multicolumn{2}{c}{$95 \% \mathrm{CI}$} & \multirow{2}{*}{$\mathrm{R}^{2}$} \\
$\begin{array}{c}\text { TDI after } \\
\text { exercise }\end{array}$ & $\begin{array}{c}\text { E'/Em' } \\
\text { Rises by 5 unit }\end{array}$ & 2.085 & 1.485 & 2.929 & $<0.001$ & $0.330^{\mathrm{a}}$ \\
\hline
\end{tabular}

${ }^{a}$ Nagelkerke $\mathrm{R}^{2}$ 
Table 6. Optimal cut-off values for investigated predictors.

\begin{tabular}{|c|c|c|c|c|c|c|c|c|c|}
\hline \multirow[b]{2}{*}{ Model } & \multirow[b]{2}{*}{ Parameter } & \multirow[b]{2}{*}{ AUC } & \multicolumn{2}{|c|}{$95 \%$ AUC } & \multirow[b]{2}{*}{$P$} & \multirow[b]{2}{*}{ cut-off } & \multirow[b]{2}{*}{ sensitivity } & \multirow[b]{2}{*}{ specificity } & \multirow[b]{2}{*}{$\begin{array}{c}\text { Nagelkerke } \\
\mathrm{R}^{2}\end{array}$} \\
\hline & & & $\begin{array}{c}\text { Lower } \\
\text { limit }\end{array}$ & $\begin{array}{l}\text { Upper } \\
\text { limit }\end{array}$ & & & & & \\
\hline TDI at rest & $\mathrm{E} / \mathrm{Em}$ & 0.797 & 0.692 & 0.901 & $<0.001$ & $\geq 16.6$ & $71 \%$ & $71 \%$ & 0.275 \\
\hline $\begin{array}{l}\text { TDI after } \\
\text { exercise }\end{array}$ & E'/Em’ & 0.837 & 0.742 & 0.933 & $<0.001$ & $\geq 18.7$ & $86 \%$ & $71 \%$ & 0.330 \\
\hline
\end{tabular}

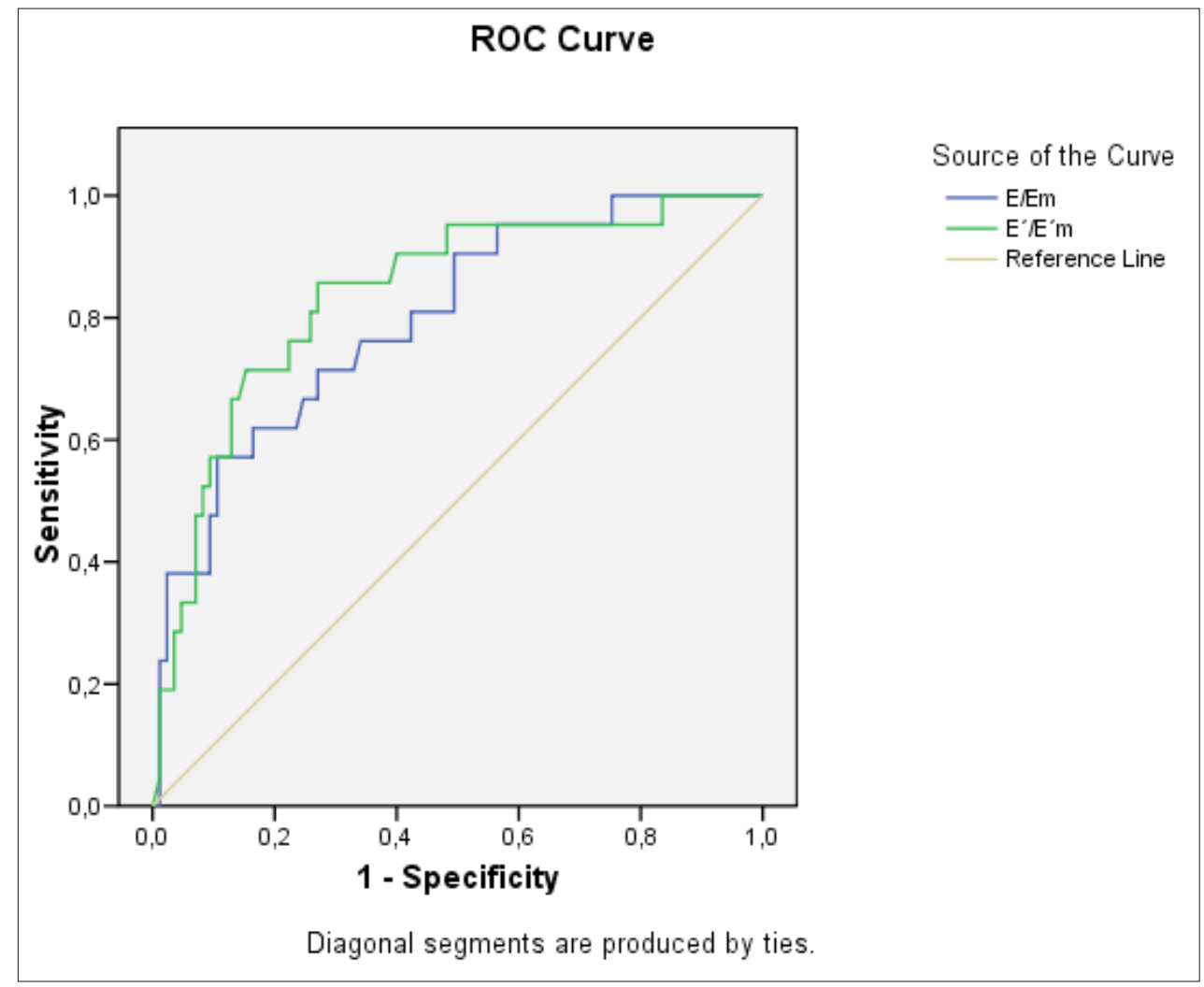

Fig. 1. Relation between sensitivity and specificity for investigated predictors. rest (without index) and after exercise (with index ') is summarized in Table 3.

Using multivariant analysis we created model A consisting of Doppler variants during rest and model B with Doppler variants after exercise.

Multivariant analysis was entered by those independent echocardiografic variables which differed significantly between both groups in univariant analysis. Moreover, the models were entered by glomerular filtration (GFR).

Model A: prediction of prognostically poor state with resting TDI parameters.

The analysis consisted of the following parameters: MR, GFR, LAvoli, Sm, E/Em. The dependent variable was the presence in group I - i.e. the presence of prognostically poor state.

Model chose one variable, that has the biggest influ- ence on the dependent variable - E/Em. Interpretation of estimated model coefficients:

If the value of $\mathrm{E} / \mathrm{Em}$ rises by 5 , the odds of prognosticaly poor staty rise 1.961 times (Table 4 ).

Model B: prediction of prognostically poor state using after exercise TDI parameters.

The analysis consisted of the following parameters: MR, GFR, LAvoli, Sm', E'/Em'. The dependent variable was the presence in the group I - i.e. the presence of prognostically poor state.

Model chose one variable with the biggest influence on the dependent variable - E'/Em'.

Interpretation of estimated model coefficients:

If the value of E'/Em' rises by 5, the odds of prognosticaly poor state rise 2.085 times (Table 5 ). 
Using the ROC curve (Fig. 1) showing the relation between sensitivity and specificity for all the possible values of numeric parameter we defined the optimal cut-off values for investigated predictors (Table 6).

\section{DISCUSSION}

Combination of low functional capacity, ventilation exercise inefficiency and high levels of BNP helps in identification of patients with poor prognosis (group I) by taking more patophysiologic mechanism into account which participate as pathogenic factors in CHF patients. A cross-sectional study of this type doesn't work with data like mortality planned study, however with regard to the size of our group and some distortions and inaccuracies connected to backward identification of death causes ${ }^{15}$ we preferred the above mentioned methodics of data processing.

Average value of $\mathrm{pVO} 2$ in prognostically poor group of patients (group I) was $0.56 \pm 0.14 \%$ (which corresponded to $12.5 \pm 3.1 \mathrm{~mL} / \mathrm{kg} / \mathrm{min}$ ). The majority of patients belonged to the gray zone regarding the usage of peak oxygen consumption in prognostic stratification of patients with CHF (ref. ${ }^{16,17}$ ). From this perspective the simultaneous usage of $\mathrm{pVO} 2$ and $\mathrm{VE} / \mathrm{VCO} 2$ slope by classification of patients from both groups according to assumed prognosis seems to be of great benefit ${ }^{18}$.

Every patient in group I had the VE/VCO2 slope higher than 32.7. Considering the fact, that $95 \%$ of patients used a betablocator, we can summarise, that this parameter-wise the cut off value used corresponding to the median was of clinical relevance, too ${ }^{19-22}$.

There is no generally accepted level of BNP by stable heart failure patients with optimal medical therapy which would clearly present a dividing line for prognosis setting. Criterium of BNP being higher than median, which was $210 \mathrm{pg} / \mathrm{mL}$, corresponds relatively well with the values characterising poor prognosis in relatively comparable data files ${ }^{23,24}$. These data confirm the significance of present BNP and pVO2 use in prognostic stratification ${ }^{24}$. Undeniable influence on the BNP is to be accounted to a high prevalence of renal insuficiency in our group ${ }^{25}$ where $38 \%$ of patients had GFR $<60 \mathrm{~mL} / \mathrm{min}$. However, it does not diminish the information value of the high level of BNP as a predictor of unfabourable prognosis, as the renal insufficience itself worsens the prognosis of these patients ${ }^{26}$

For identification of patients with poor prognosis (group I) we can state, that the cut-off values used in all the parameters correspond to earlier verified prognostic boundary values. It should enable selection of prognostic poor patients with acceptable sensitivity, on the other hand using of three objective parameters together contributes to the presumption of a good selection specificity. Similar to other authors we observed a difference between the patients of the two groups characterized by the tissue Doppler parameters of left ventricle longitudinal function during rest and after exercise, by the ratio $\mathrm{E} / \mathrm{Em}$, indexed left ventricle volume and the level of mitral regurgitation ${ }^{5,11,27-29}$. In both of our models the only independent echocardiographic predictor of a poor prognosis, similarly to other published data ${ }^{5,11}$, was the parameter E/Em (during rest or after exercise). Adding other parameters into both models did not improve their discriminative ability any further. It is probably caused by the fact, that these parameters either reflect the same left ventricular diastolic dysfunction or the left ventricular filling pressure ${ }^{30}$ respectively, or they influence each other to a certain extent ${ }^{31,32}$. As shown by the ROC analysis, the difference in the prognostic accuracy between resting and post-exercise cutoff $\mathrm{E} / \mathrm{Em}$ ratios is expressed mainly in the area of middle values. Within the range of 12-17 of resting E/Em ratio all the cut-off values demonstrate lower accuracy in the prognostic stratification of our group of patients in comparison with cut-off post- exercise E'/Em' valueswithin the range of $15-21$. We consider this as a clinically important finding, because the previously published works defined the optimal resting E/Em poor prognosis prediction cut-off in the range of $12-16^{5,11,33}$. We reached a practically same conclusion for the value of 16.6 .

The only so far published work comparing the resting and exercise $\mathrm{E} / \mathrm{Em}$ ratio in the prediction of function capacity of patients with heart failure concludes, that the $\mathrm{E} / \mathrm{Em}$ ratio at the peak of the exercise higher than 18.2 predicted a peak oxygen consumption lower than $14 \mathrm{~mL} / \mathrm{kg} / \mathrm{min}$ with sensitivity of $85.2 \%$ and specificity of $95.6 \%$ (ref. $^{34}$ ). These authors enrolled only patients with ischemic heart failure etiology and with sinus rhythm. Remarkably, in our work the post-exercise E/Em value of $\geq 18.7$ was the optimal cut-off for prediction of not only of low function capacity, but also more complex combined poor prognosis indicator.

\section{LIMITATION}

Patients with mitral regurgitation with calculated ERO $>0.2 \mathrm{~cm}^{2}$ were excluded because of the possibility of distortion of $\mathrm{E} / \mathrm{Em}$ and left ventricular filling pressure relationship ${ }^{12}$. Thus the conclusions of our work should not be applied for patients with serious ischemic or secondary mitral regurgitation.

The right ventricular function (assessed using the maximal systolic tricuspidal annulus movement speed) was not included in multidimensional analysis because patients in both groups showed borderline nonsignificant difference in this parameter. In both groups it was lower than $10.8 \mathrm{~cm} / \mathrm{s}$. These values were related with poor prognosis previously by Meluzin et al. ${ }^{35}$

We investigated rather heterogeneous group of patients of wide age range, suffering from either ischemic or nonischemic etiology of heart failure, high prevalence of renal insufficiency and partially with atrial fibrillation. These facts could influence the sensitivity and specificity of tested parameters. On the other side our results reflects more closely the daily practise. 


\section{CONCLUSIONS}

In our work we confirmed the significance of the E/ Em parameter in prognostic stratification of patients with heart failure and its superiority over traditional echocardiographic parameters. Further, our results indicate a better potential of post-exercise measurement of this parameter in prognostic stratification of patients with heart failure with depressed left ventricular systolic function.

\section{ABBREVIATIONS}

BNP, B-type of natriuretic peptide; CAD, Coronary artery disease; CHF, Chronic heart failure; DCMP, Dilatative cardiomyopathy; E, Peak velocity of early diastolic filling of mitral inflow at rest; E', Peak velocity of early diastolic filling of mitral inflow after exercise; EDVi, End-diastolic left ventricular volume indexed to body surface; Em, Average of peak early diastolic velocity of the septal and lateral mitral anulus at rest; Em', Average of peak early diastolic velocity of the septal and lateral mitral anulus after exercise; ERO, Effective mitral regurgitant orifice area; ESVi, End-systolic left ventricular volume indexed to body surface; GFR, Glomerular filtration according to Cocroft-Gault formula; LAvoli, Left atrial volume indexed to body surface; LVEF, Left ventricular ejection fraction; MR, Mitral regurgitation; pVO2, Peak oxygen consumption; RER, Respiratory exchange ratio; $\mathrm{Sm}$, Average of systolic velocity of the septal and lateral mitral anulus at rest; Sm', Average of systolic velocity of the septal and lateral mitral anulus after exercise; Stri, Systolic velocity of tricuspid anulus; TDI, Tissue Doppler imaging; VCO2, Rate of elimination of Carbon Dioxide; VE, Minute ventilation; VO2, Oxygen uptake.

\section{REFERENCES}

1. Spinar J, Hradec J, Meluzin J, Spac J, Spinarova L, Vitovec J, Lupinek P Malek I. Doporuceni pro diagnostiku a lecbu chronickeho srdecniho selhani CKS 2006. Cor Vasa 2008;50(1):K5-K22.

2. Grayburn PA, Appleton CP,De Maria AN, Greenberg B, Lowes $B$, Oh J, Plehn JF, Rahko P, St John Sutton M, Eichhorn EJ on behalf of the BEST trial Echocardiographic Substudy Investigators. Echocardiographic predictors of morbidity and mortality in patients with advanced heart failure. J Am Coll Cardiol 2005;45:1064-71.

3. Wong M, Stazewsky L, Latini R, Barlera S, Glazer R, Aknay N, Hester A, Anand I, Cohn JN. Severity of left ventricular remodeling defines outcomes and response to therapy in heart failure. J Am Coll Cardiol 2004:43:2022-7.

4. Wang M, Yip G, Yu CM, Zhang Q, Zhang Y, Tse D, Kong SL, Sanderson JE. Independent and incremental prognostic value of early mitral annulus velocity in patients with impaired left ventricular systolic function. J Am Coll Cardiol 2005;45:272-7.

5. Acil T, Richter T, Stypmann J, Janssen F, Paul M, Grude M, Scheld $\mathrm{HH}$, Breithardt G, Bruch C. Prognostic value of tissue Doppler imaging in patients with chronic congestive heart failure. Int J Cardiol 2005; 103:175-81.

6. Meluzin J, Spinarova L, Hude P, Krejci J, Dusek L, Vitovec J, Panovsky R. Combined right ventricular systolic and diastolic dysfunction represents a strong determinant of poor prognosis in patients with symptomatic heart failure. Int J Cardiol 2005;105(2):164-73.

7. Burgess MI, Jenkins C, Sherman JE, MarwickTH. Diastolic stress echo- cardiography: hemodynamic validation and clinical significance of estimation of ventricular filling pressure with exercise. J Am Coll Cardiol 2006;47:1891-900.

8. Lang RM, Bierig M, Devereux RB, Flachskampf FA, Foster E, Pellika PA, Picard MH, Roman MJ, Seward J, Shanewise JS, Solomon SD, Spencer KT, Sutton MS, Stewart WJ. Recommendations for chamber quantification: a report from the American Society of Echocardiography's guidelines and standards committee and the chamber quantification writing group, developed in conjuction with the European Association of Echocardiography, a branch of the European Society of Cardiology. J Am Soc Echocardiogr 2005;18:1440-63.

9. Bargigia GS, Tronconi L, Sahn DJ, Recusani F, Raisaro A, De Serni $\mathrm{S}$, Valdes-Cruz LM, Montemartini C. A new method for quantification of mitral regurgitation based on color flow Doppler imaging of flow convergence proximal to regurgitant orifice. Circulation 1991;84:1481-9.

10. Smart N, Haluska B, Leano R, Case C, Mottram PM, Marwick TH. Determinants of functional capacity in patients with chronic heart failure:Role of filling pressure and systolic and diastolic function. Am Heart J 2005;149(1):152-8.

11. Dokainish H, Zoghbi WA, Lakkis NM, Ambriz E, Patel R, Quinones MA, Naqueh SF. Incremental predictive power of B-type natriuretic peptide and tissue Doppler echocardiography in the prognosis of patients with congestive heart failure. J Am Coll Cardiol 2005;45:1223-6.

12. Nagueh SF, Appleton CP, Gillebert TC, Marino PN, Oh JK, Smiseth OA, Waggoner AD, Flachskampf FA, Pellika PA, Evangelisa A. Recommendation for the evaluation of left ventricular diastolic function by echocardiography. Eur J Echocardiogr 2009;10(2):165-93.

13. Grewal J, McCully RB, Kane GC, Lam C, Pellika PA. Left ventricular function and exercise capacity. JAMA 2009;301(3):286-94.

14. Oh JK, Seward JB, Tajik AJ. The echo manual.3rd edition.Rochester: Mayo Foundation for Medical Education and Research, 2007.

15. Uretsky BF, Thygesen K, Armstrong PW, Cleland JG, Horowitz JD, Massie BM, Packer M, Poole-Wilson PA, Ryden L. Acute coronary findings at autopsy in heart failure patients with sudden death:results from the assessment of treatment with lisinopril and survival (ATLAS) trial. Circulation 2000;102:611-6.

16. Lupinek P. Prognosticka stratifikace nemocnych s chronickym srdecnim selhanim. Kardioforum 2004;1:10-4.

17. Jessup M, Abraham WT, Casey DE, Feldman AM, Francis GS, Ganiats TG, Konstam MA, Mancini DM, Rahko PS, Silver MA, Stevenson LW, Yancy CW. 2009 Focused update: ACCF/AHA guidelines for the diagnosis and management of heart failure in adults. J Am Coll Cardiol 2009:53:1343-82.

18. Arena R, Humphrey R. Comparison of ventilatory expired gas parameters used to predict hositalization in patients with heart failure. Am Heart J 2002;143:427-32.

19. Chua TP, Ponikowski $P$, Harrington D, Anker SD, Webb-Peploe K, Clark AL, Poole-Wilson PA, Coats AJ. Clinical correlates and prognostic significance of the ventilatory response to exercise in chronic heart failure.J Am Coll Cardiol 1997;29:1585-90.

20. Ponikowski P, Francis DP, Piepol MF, Davies LC, Chua TP, Davos CH, Florea V, Banasiak W, Poole-Wilson PA, Coats AJ, Anker SD. Enhanced ventilatory response to exercise in patients with chronic heart failure and preserved exercise tolerance: marker of abnormal cardiorespiratory reflex control and predictor of poor prognosis. Circulation 2001;103:967-72.

21. Agostini P, Guazzi M, Bussotti M, De Vita S, Palermo P. Carvedilol reduces the inappropriate increase of ventilation during exercise in heart failure patients. Chest 2002;1226:2062-7.

22. Agostini P, Apostolo A, Cattadori G, Salvioni E, Berna G, Antonioli L, Vignati C, Schina M, Sciomer S, Bussotti M, Palermo P, Fiorentini $C$, Contini M. Effects of $\beta$-blockers on ventilation efficiency in heart failure. Am Heart J 2010;159(6):1067-73.

23. Nishii $M$, Inomata T, Takehana $H$, Naruke T, Yanagisawa T, Moriquchi M, Takeda S, Izumi T. Prognostic utility of B-type natriuretic peptide assessment in stable low-risk outpatients with nonischemic cardiomyopathy after decompensated heart failure. J Am Coll Cardiol 2008;51:2329-35.

24. De Groote P, Dagorn J, Soudan B, Lamblin N, McFadden E, Bauters C. B-type natriuretic peptide and peak exercise oxygen consumption provide independent information for risk stratification in patients with stable congestive heart failure. J Am Coll Cardiol 2004;43:1584-9. 
25. Tsutamoto T, Wada A, Sakai H, Ishikawa C, Tanaka T, Hayashi M, Fujii M, Yamamoto T, Dohke T, Ohnishi M, Takashima H, Kinoshita M, Horie M. Relationship between renal function and plasma brain natriuretic peptide in patients with heart failure. J Am Coll Cardiol 2006;47:5826.

26. Anavekar NS, McMurray JJ, Velazquez EJ, Solomon SD, Kober L, Rouleau JL, White HD, Nordlander R, Maggioni A, Dickstein K, Zelenkofske S, Leimberger JD, Califf RM, Pfeffer MA. Relation between renal dysfunction and cardiovascular outcomes after myocardial infarction. N Engl J Med 2004;351:1285-95.

27. Junker A, Thayssen P, Nielsen B, Andersen PE. The hemodynamic and prognostic significance of echo-Doppler-proven mitral regurgitation in patients with dilated cardiomyopathy. Cardiology 1993;83:14-20.

28. Grigioni F, Enriquez-Sarano M, Zehr KJ, Bailey KR, Tajik AJ. Ischemic mitral regurgitation: long-term outcome and prognostic implications with quantitative Doppler assessment. Circulation 2001;103:1759-64.

29. Moller JE, Hollis GS, Oh JK, Seward JB, Reeder GS, Wright RS, Park SW, Bailey KR, Pellika PA. Left atrial volume: a powerful predictor of survival after acute myocardial infarction. Circulation 2003;107:220712.

30. Tsang T, Barnes B, Gersh B, Bailey KR, Seward JB. Left atrial volume as a morphophysiologic expression of left ventricular distolic dys- function and relation to cardiovascular risk burden. Am J Cardol 90;2002:1284-9.

31. Van de Veire NR, De Sutter J. Effect of ischemic mitral refurgitation on the ratio of early transmitral flow velocity to mitral annulus early diastolic velocity in patients with stable coronary artery disease. Am J Cardiol 2006;97:1449-51.

32. Yip GW, Zhang Y, Tan PY, Wang M, Ho PY, Brodin LA, Sanderson JE. Left ventricular long-axis changes in early diastole and systole:impact of systolic function on diastole. Clinical Science 2002;102:515-22.

33. Troughton RW, Prior DL, Frampton CM, Nash PJ, Pereira JJ, Martin M, Fogarty A, Morehead AJ, Straling RC, Young JB, Thomas JD, Lauer MS, Klein AL. Usefulness of tissue Doppler and color M-mode indexes of left ventricular diastolic function in predicting outcomes in systolic left ventricular heart failure (from ADEPT Study). Am J Cardiol 2005;96:257-62.

34. Podolec P, Rubis P, Tomkiewicz-Pajak L, Kopec G, Tracz W. Usefulness of the evaluation of left ventricular diastolic function changes during stress echocardiography in predicting exercise capacity in patients with ischemic heart failure. J Am Soc Echocardiogr 2008;21(7):83440.

35. Meluzin J, Spinarova L, Dusek L, Toman J, Hude P, Krejci J. Prognostic importance of the right ventricular function assessed by Doppler tissue imaging. Eur J Echocardiogr 2003;4(4):262-71. 